This is the author's final, peer-reviewed manuscript as accepted for publication. The publisher-formatted version may be available through the publisher's web site or your institution's library.

\title{
Decline in firing technology or poorer fuel resources? High- temperature thermoluminescence (HTTL) archaeothermometry of Neolithic ceramics from Pool, Sanday, Orkney
}

Joel Q. G. Spencer, David C. W. Sanderson

\section{How to cite this manuscript}

If you make reference to this version of the manuscript, use the following information:

Spencer, J. Q. G., \& Sanderson, D. C. W. (2012). Decline in firing technology or poorer fuel resources? High-temperature thermoluminescence (HTTL) archaeothermometry of Neolithic ceramics from Pool, Sanday, Orkney. Retrieved from http://krex.ksu.edu

\section{Published Version Information}

Citation: Spencer, J. Q. G., \& Sanderson, D. C. W. (2012). Decline in firing technology or poorer fuel resources? High-temperature thermoluminescence (HTTL) archaeothermometry of Neolithic ceramics from Pool, Sanday, Orkney. Journal of Archaeological Science, 39(12), 3542-3552.

Copyright: @ 2012 Elsevier Ltd.

Digital Object Identifier (DOI): doi:10.1016/j.jas.2012.05.036

Publisher's Link: http://www.sciencedirect.com/science/article/pii/S0305440312002865

This item was retrieved from the K-State Research Exchange (K-REx), the institutional repository of Kansas State University. K-REx is available at http://krex.ksu.edu 
This is the author's final, peer-reviewed manuscript as accepted for publication. The publisher-formatted version may be available through the publisher's web site or your institution's library.

This item was retrieved from the K-State Research Exchange (K-REx), the institutional repository of Kansas State University. K-REx is available at http://krex.ksu.edu 


\title{
Decline in firing technology or poorer fuel resources? High-temperature thermoluminescence (HTTL) archaeothermometry of Neolithic ceramics from Pool, Sanday, Orkney
}

Joel Q.G. Spencer $^{\mathrm{a}, *}$, David C.W. Sanderson ${ }^{\mathrm{b}}$

${ }^{a}$ Department of Geology, Kansas State University, Manhattan, Kansas 66506, USA

${ }^{\mathrm{b}}$ Scottish Universities Environmental Research Centre, East Kilbride, Glasgow, G75 OQF, Scotland, UK

* Corresponding author. Tel.: +1 (785) 532 2249; fax: +1 (785) 532 5159. E-mail address: joelspen@ksu.edu (J.Q.G. Spencer).

\begin{abstract}
The Neolithic ceramic assemblage from the multi-period coastal settlement at Pool on the island of Sanday, Orkney is unique because it stratigraphically spans both the earlier roundbased (including possible Unstan bowls) and later flat-based ('Grooved Ware') traditions. High-temperature thermoluminescence (HTTL) analysis objectively demonstrates that ceramics from the earliest Neolithic layers have been consistently better fired compared to examples from later layers. We suggest two interpretations of these data: either firing technology declined with changing social structures and/or adoption of a different ceramic tradition or that there was greater pressure on fuel resource and management in the later Neolithic. Paleoenvironmental and chronological evidence indicate climatic deterioration in the later Neolithic, which adds further support to an interpretation of a poorer fuel resource at that time. In addition to studies of the HTTL signal, analysis of the ambient temperature modification of the TL signal has potential to support or evaluate dating evidence, and is readily applicable to optically stimulated luminescence (OSL) age data.
\end{abstract}




\section{Highlights}

$>$ We have studied high-temperature thermoluminescence of Neolithic ceramics from Pool $>$ Ceramics from earliest Neolithic are consistently better fired than later examples $>$ Reduced thermal exposure correlates with poorer fuel resources and palaeoclimate $>$ Ambient temperature TL identifies stratigraphic relationships in luminescence ages

Keywords: Orkney Neolithic; Ceramics; High-Temperature Thermoluminescence; Thermal Exposure; Firing Technology; Fuel Resources; Palaeoclimate

\section{Introduction}

The multi-period coastal settlement at Pool on the island of Sanday in Orkney (Fig. 1) was investigated seasonally between 1983 and 1988 (Hunter and MacSween, 1991; Hunter, 2000; Hunter et al., 2007). The Neolithic deposits formed a large mound covering an area $\sim 75 \mathrm{~m}$ in diameter with a maximum depth of $\sim 1.5 \mathrm{~m}$. The mound was created by gradual deposition of hearth debris and associated midden, pottery and faunal/floral material, producing a number of tipping layers reddish-brown or darker in colour. Tipping, akin to dumping settlement debris, was a deliberate activity that may have had a functional purpose (e.g. structural or thermal) aside from convenience; the tipping layers have a greater 
concentration in association with the mound core, and possess a variety of depositional angles (Hunter et al., 2007). Fourteen Neolithic buildings were identified in the excavation area positioned throughout the depositional sequence; above, surrounded by and below the tip-like deposits. Of main interest for this study is the ceramic sequence, which at Pool is unique because it stratigraphically spans both the round-based (including possible Unstan bowls) and flat-based (Grooved Ware type) traditions. The site phasing, which generally refers to a sequence of temporally and spatially restricted archaeological units defined by specific artefacts or other cultural traits, was developed for the Neolithic layers on alterations in the dynamics of deposition (Hunter et al., 2007). The ceramics have been assigned to three main phases (Table 1), and with further formation and chronological divisions comprise 8 sub-phases $(1.1,1.2,2.1,2.2,2.3 \mathrm{a}, 2.3 \mathrm{~b}, 3.1$ and 3.2).
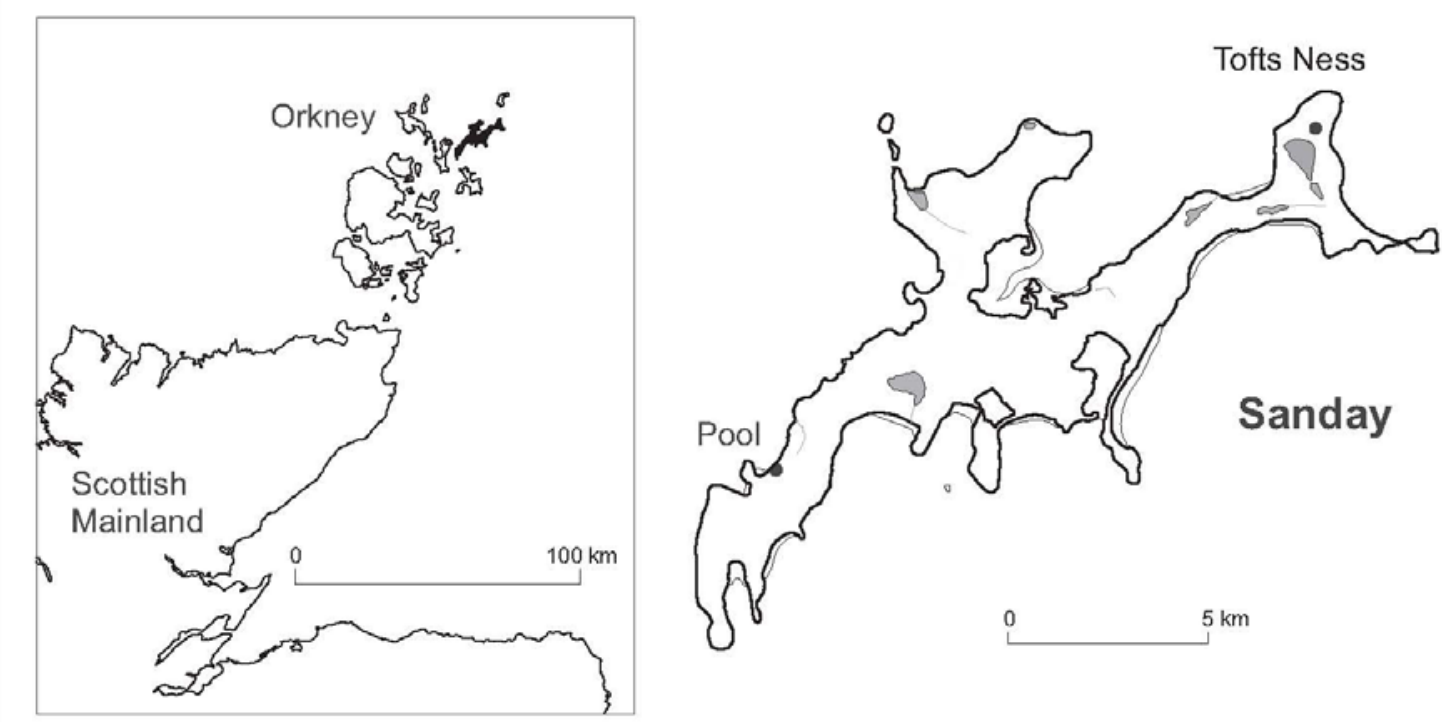

Figure 1. Location of the Neolithic settlement at Pool on Sanday, one of the seventy or so Orkney islands. 
By exploiting the thermal exposure dependence of thermoluminescence (TL) characteristics of feldspar minerals (e.g., Spencer and Sanderson, 1994; Spencer, 1996), we sought to ascertain if we could identify different thermometric properties from ceramics from early phases compared with those from later phases. We were interested to determine whether change in Neolithic ceramic tradition was accompanied by change in firing technology, and also if we could identify ambient temperature changes that correlated with TL chronology.

Table 1. Summary of phasing, ceramic artefacts, and analysed sherds for the Pool Neolithic

\begin{tabular}{|c|c|c|c|c|c|}
\hline \multirow[t]{2}{*}{ Phase } & \multicolumn{3}{|c|}{ Summary of ceramic evidence ${ }^{2}$} & \multicolumn{2}{|c|}{ Samples analysed $^{b}$} \\
\hline & Type & Temper & Decoration & No. sherds & No. TL dates \\
\hline 1.1 & \multirow{2}{*}{ Round-based; possible Unstan bowls } & \multirow{2}{*}{ Occasional shell } & \multirow{2}{*}{ Mainly undecorated } & 8 & 10 \\
\hline 11.2 & & & & - & - \\
\hline 2.1 & \multirow{4}{*}{ 'Baggy' \& flat-based vessels } & \multirow{4}{*}{ Shell } & \multirow{4}{*}{ Incision } & 10 & 10 \\
\hline 2.2 & & & & 10 & 10 \\
\hline $22.3 \mathrm{a}$ & & & & 10 & 10 \\
\hline $2.3 \mathrm{~b}$ & & & & 10 & 10 \\
\hline 3.1 & \multirow{2}{*}{ Bucket-shaped } & \multirow{2}{*}{ Mainly rock } & \multirow{2}{*}{ Applied } & 5 & 10 \\
\hline 3.2 & & & & - & - \\
\hline \multicolumn{6}{|c|}{ "Modified from Hunter and MacSween (1991) } \\
\hline \multirow{2}{*}{\multicolumn{6}{|c|}{$\begin{array}{l}\text { 'Sample numbers only include those from the Neolithic layers. A further } 15 \text { TL dates were from samples from Late Iron } \\
\text { Age Phases } 5.2 \text { and } 6.1 \text { (see Section } 1 \text { and Table A.1) }\end{array}$}} \\
\hline & & & & & \\
\hline \multicolumn{6}{|c|}{$\begin{array}{l}\text { 'Two alkali feldspar mineral separates were dated from selected samples from Phases } 1.1 \text { and } 3.1 \text { to provide a total of } 10 \\
\text { dates for each phase (see Table A.1 for details) }\end{array}$} \\
\hline
\end{tabular}

Forty-eight samples with individual finds codes and context numbers, the majority comprising single pottery sherds excavated from layers identified with the Pool Neolithic, were submitted for TL dating at the Scottish Universities Environmental Research Centre (SUERC) luminescence laboratories. Multiple samples were submitted from each of 6 subphases $(1.1,2.1,2.2,2.3 \mathrm{a}, 2.3 \mathrm{~b}$ and 3.1 , comprising $8,10,10,10,5$ and 5 sherds, respectively). By dating two different alkali feldspar mineral separates from selected samples the TL dataset comprises 60 dates (10 from each phase) from the Neolithic layers, whose mean TL ages have been previously discussed (Hunter, 2000; Hunter et al., 2007). In this work, TL thermometric properties of alkali feldspar mineral separates from 30 of the 
Pool Neolithic samples selected from the SUERC laboratory archive of pre-prepared minerals were investigated. Of these samples, 27 had TL dates broadly consistent with, and indeed defining the chronology of site phasing, which divides broadly into Early and Late Neolithic periods. The remaining 3 come from a transitional layer containing both Early and Late Neolithic material (see Section 3 for details). For completeness, in the following section we provide details of the TL dating procedures used in this early work from the SUERC laboratory, and results for samples from both Neolithic (48 sherd samples; 60 dates) and Iron Age (10 sherd samples and fragments of 1 hearthstone; 15 dates) layers from Pool.

\section{TL chronology}

TL dates were measured on alkali feldspars separated from the sherds using procedures adapted from those developed for burned stones (e.g. Mejdahl and Winther-Nielsen, 1982; Mejdahl, 1983, 1985; Sanderson et al., 1985, 1988). All procedures were carried out under low-intensity safe-lighting. The sherds were dried in a $50^{\circ} \mathrm{C}$ oven and a small portion of each sherd was retained to estimate saturated water content. The outer few $\mathrm{mm}$ of the remainder of each dried sherd was removed. The sherd was gently disaggregated and initially sieved to pass through a $500-\mu \mathrm{m}$ mesh to minimise grain fracturing. The remainder was sieved into different grain size fractions. K-rich $\left(2.51-2.58 \mathrm{gcm}^{-3}\right)$, Na-rich $(2.58-2.62$ $\left.\mathrm{gcm}^{-3}\right)$ and plagioclase $\left(2.62-2.74 \mathrm{gcm}^{-3}\right)$ feldspars were separated from selected grain size fractions using sodium polytungstate liquid of different densities and a centrifuge. All 
feldspar fractions were treated with $10 \% \mathrm{HF}$ for $10 \mathrm{~min}$, followed by a $30 \mathrm{~min} \mathrm{HCl}$ treatment, $\mathrm{H}_{2} \mathrm{O}$ and acetone washing and oven drying.

Palaeodose $(\mathrm{P})$ values were estimated using an equal-predose multiple-aliquot additive dose procedure (e.g. Sanderson et al., 1988). For each of 8 sample aliquots an incremental beta dose was added to the natural for first glow $(n+\beta) T L$, and then the same dose was administered in reverse order for second glow ( $\beta$ ) TL, each disc having received the same total radiation dose (equal predose) before normalisation measurements and fading tests were conducted. Sixteen-hour preheating stages at $125-140^{\circ} \mathrm{C}$ prior to each TL readout stage were incorporated to minimise the presence of thermally unstable TL components, and prolonged fading tests over 2-3 month storage periods (following suggestions of Sanderson, 1988a). The 8 weighed aliquots (typically $5 \mathrm{mg}$ ) of each sample were mounted on thin $(\sim 0.25 \mathrm{~mm}) 1$-cm-diameter stainless-steel discs using silicon grease for these determinations. Samples were irradiated with a $4-\mathrm{cm}^{2}$ active area ${ }^{90} \mathrm{Sr} /{ }^{90} \mathrm{Y}$ source, similar to that described by Sanderson and Chambers (1985), configured to produce a uniform radiation field in the sample plane. TL glow curves were measured from ambient to $500^{\circ}$ at $5^{\circ} \mathrm{Cs}^{-1}$ using a SUERC TL reader. Irradiation and readout were performed using laborious manual procedures at this stage in the laboratory development (automated readout and irradiation facilities were also developed later on).

The beta dose rate was assessed using thick source beta counting (TSBC) (Sanderson, 1988b) on a portion of dried bulk sample, and a subsample of several $100 \mathrm{mg}$ taken and finely powdered for neutron activation analysis (NAA) of $\mathrm{U}$, Th and $\mathrm{K}$, using the former 
Scottish Universities Research Reactor Centre (SURRC) 300 kW UTR research reactor. Total sample dose-rates were calculated by combining estimated internal $\mathrm{K}$ dose rate contributions (based on typical assumed concentrations for the appropriate density fraction following the analyses reported by Sanderson et al., 1988, combined with absorbed dose fractions after Mejdahl, 1979) with effective matrix beta dose rates based on combining TSBC and NAA results (taking account of estimated water contents and absorbed dose fractions), external gamma dose-rates based on site averages from in-situ gamma spectrometry measurements and cosmic dose-rates assessed from geomagnetic latitude, altitude and burial depth below ground surface.

Details of excavated sherds analysed and a summary of TL dating results are given in an appendix (Table A.1). Typical level of precision in equivalent dose (ED) estimates was about $6 \%$. Average fading quotient was $0.96 \pm 0.02$, representing the mean ratio of sensitization-independent stored-to-prompt signals (after Sanderson, 1988) for the whole decay period. The log cycles of time over which fading data were registered were between 5 to 7 orders of magnitude (in seconds). This equates to mean fading rates of $1-2 \%$ per decade registered over the $5^{\text {th }}$ to $7^{\text {th }}$ decade of time following irradiation and evaluated over plateau temperatures. Alexander (2007) found similar levels of fading from a range of geological feldspars subsequent to comparable prolonged preheating regimes to those reported here. 


\section{High-temperature thermoluminescence (HTTL): background, samples and} measurement

The existence of deep traps which might give rise to high-temperature TL (HTTL) signals above the typical $500^{\circ} \mathrm{C}$ range associated with ceramic TL can be inferred from prior HTTL studies of deep traps in dosimetry materials such as $\mathrm{CaF}_{2}$ (e.g., El-Kolaly et al., 1980; Ganguly and Kaul, 1984; Sunta, 1979) and studies of charge phototransferred from deep TL traps (commonly known as phototransferred TL or PTTL) of feldspars, zircon, fluorapatite, quartz and $\mathrm{CaF}_{2}$ using prior UV light exposure (e.g., Bailiff, 1976; Bowman, 1979; Sunta, 1979). Part of the motivation behind PTTL studies was the attempt to isolate a stable signal to overcome anomalous fading (Wintle, 1973, 1977). Valladas and co-workers studied the same problem by investigating deep traps of the HTTL signal in feldspars (Brou and Valladas, 1975; Guérin and Valladas, 1980; Valladas et al., 1979) and successfully dated HTTL of labradorite from lava samples, similar to material that Wintle (1973) first observed anomalous fading. Evidence that deep traps giving rise to HTTL in feldspars were potentially more widespread than had hitherto been demonstrated was also recognised in earlier TL dating programs of vitrified forts (Sanderson et al., 1985, 1988) and in the ceramic dating work described in Section 2. This has now been confirmed for a wide range of samples (Spencer, 1996) once a specially adapted TL reader (described below) was constructed. 
Spencer and Sanderson: HTTL archaeothermometry of Neolithic ceramics from Pool

Of the 30 sherds we investigated in this study, 18 were assigned to 'Early Neolithic' Phases (1.1, 2.1 and 2.2) and 12 from 'Late Neolithic' Phases (2.3a, 2.3b and 3.1) (Table 2). TL dates for samples from Phases 1.1 and 2.1 range from 2930 to $4260 \mathrm{BC}$ and 3370 to 4080 BC, respectively. In Phase 2.2, TL results appear to be bimodal with 4 samples ranging from 3310 to $3950 \mathrm{BC}$ and the remaining 3 considerably younger from 1700 to $2100 \mathrm{BC}$. In Phases $2.3 \mathrm{a}, 2.3 \mathrm{~b}$ and 3.1 , results are broadly consistent and range from 1840 to $2370 \mathrm{BC}$, 2020 to $2110 \mathrm{BC}$ and 1870 to $2170 \mathrm{BC}$, respectively. Of these 30 samples, 27 were Na-rich feldspar, 2 were K-rich feldspar (lab. numbers SUTL78a and SUTL126) and the final sample was plagioclase feldspar (SUTL50). Grain sizes were all 90-125 $\mu \mathrm{m}$. The feldspar minerals selected partly depended on the available pre-prepared material remaining in the laboratory archive after TL dating procedures had been completed.

In a similar fashion to disc preparation described in Section 2 above, $\sim 5 \mathrm{mg}$ of each sample was mounted on stainless-steel sample discs using silicon grease. High-temperature TL (HTTL) glow-curves were measured in a linear fashion from ambient to $700^{\circ} \mathrm{C}$ at $5^{\circ} \mathrm{Cs}^{-1}$ using a specially constructed SUERC TL reader with light emission detected using a Thorn EMI 9883QB photomultiplier tube with a UV detection window (3 mm Corning 7-51 and 3 mm Schott BG39) to reduce black-body emission while maintaining adequate signal intensity (Spencer and Sanderson, 1994; Spencer, 1996). Firstly, natural HTTL was measured (Fig. 2a). Remaining on their stainless-steel disc mounts, the feldspar samples were then given a gamma radiation dose of $\sim 200 \mathrm{~Gy}$ from a ${ }^{60} \mathrm{Co}$ source (dose-rate $\sim 1$ $\mathrm{kGyh}^{-1}$ ), annealed for 30 minutes at $200^{\circ} \mathrm{C}$ in a muffle furnace on a temperature-sensed 
copper plate, and allowed to cool in the laboratory. The laboratory induced HTTL was then measured (Fig. 2b).
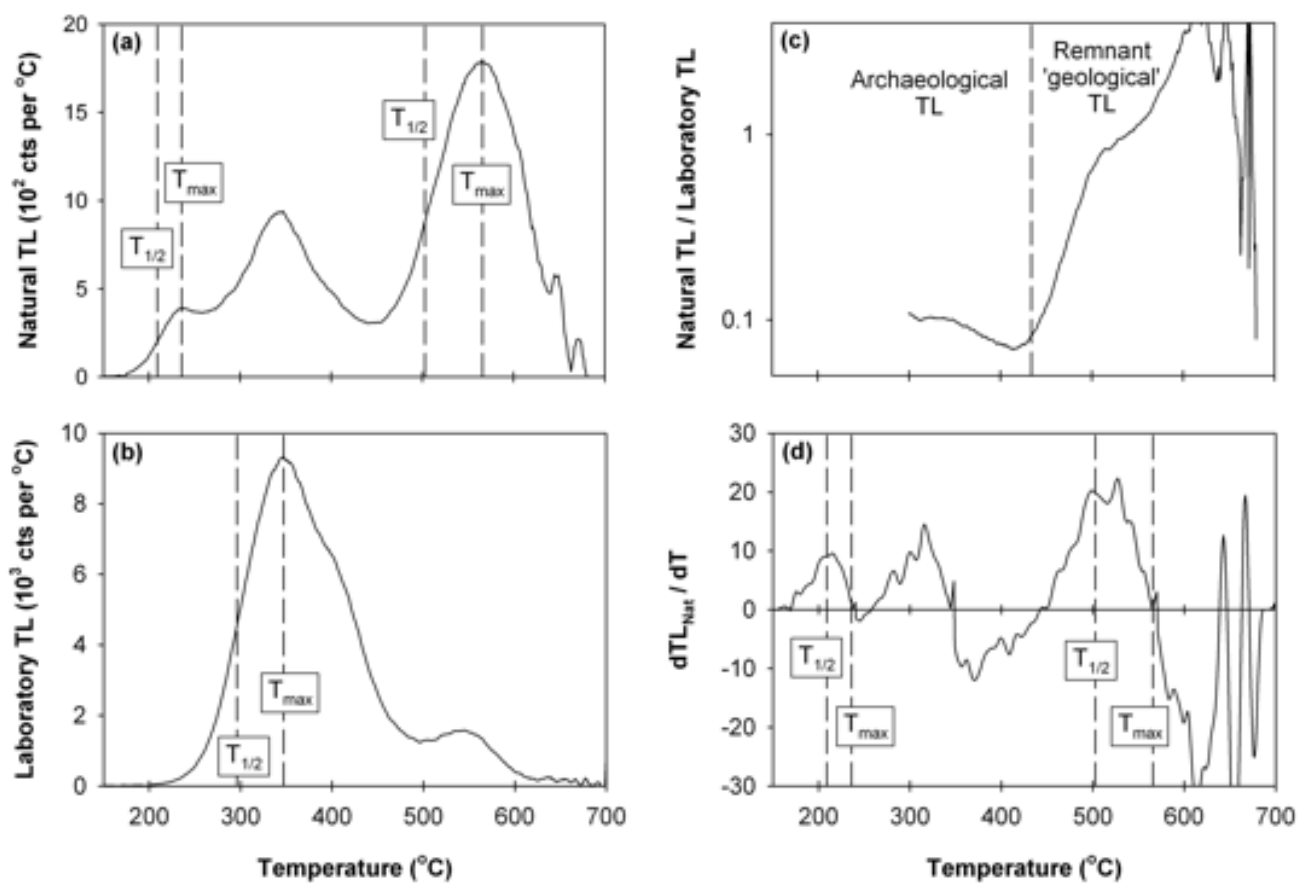

Figure 2. HTTL glow-curves from a 90-125 $\mu \mathrm{m}$ plagioclase feldspar extracted from ceramic sample SUTL50. (a) Net-natural glow-curve (background subtracted) with temperature parameters $T_{\max }$ and $T_{1 / 2}$ shown on the first peak of the archaeological HTTL and on the remnant 'geological' HTTL peak; (b) Netlaboratory glow-curve measured subsequent to $\sim 200 \mathrm{~Gy}$ gamma dose and $200^{\circ} \mathrm{C}$ anneal for $30 \mathrm{~min}$. $\mathrm{T}_{\max }$ and $\mathrm{T}_{1 / 2}$ shown on the annealed laboratory HTTL peak; (c) Natural HTTL divided by laboratory HTTL. Rapid rise in ratio after $\sim 435^{\circ} \mathrm{C}$ confirms presence of remnant 'geological' HTTL; (d) First derivative of natural HTTL glow-curve. $\mathrm{T}_{1 / 2}$ and $\mathrm{T}_{\max }$ parameters identified from (a) are shown to approximate to maxima and minima positions, respectively.

\section{HTTL thermometry analysis}

The large peak above $\sim 450^{\circ} \mathrm{C}$ in Figure 2a we interpret as the remnant 'geological' HTTL that was not removed during firing of the ceramic in the Neolithic. This interpretation is confirmed with a plateau plot (cf. Aitken, 1985) of the ratio of natural HTTL (Fig. 2a) to laboratory HTTL (Fig. 2b). This result is shown in Figure 2c; the rapid increase in values 
Spencer and Sanderson: HTTL archaeothermometry of Neolithic ceramics from Pool

after $\sim 435^{\circ} \mathrm{C}$ (note log scale) confirms presence of a comparatively large quantity of stored charge in the feldspar. For a TL temperature of $>500^{\circ} \mathrm{C}$ the ratio rises above unity, representing radiation doses in excess of the $\sim 200$ Gy gamma laboratory dose. Since the palaeodose $(\mathrm{P})$ we measure from TL from Neolithic samples ranges from $\sim 8$ to $25 \mathrm{~Gy}$ (Table A.1), it follows that the signal above $\sim 435^{\circ} \mathrm{C}$ represents accumulation due to radiation exposure over a time-scale far exceeding the archaeological age. An investigation of dose saturation level and daylight bleaching characteristics of the HTTL peaks was not part of the aims of this study, and it remains likely that the HTTL stored dose is connected to the depositional age of sediments at some earlier time in the Quaternary period. For the purposes of this work, and following terminology of Aitken (1985) and his preceding work on TL dating we refer to this HTTL signal as remnant 'geological' TL. Below $\sim 435^{\circ} \mathrm{C}$, in this example, is the archaeological TL, which has developed since removal of the previous signal by ancient firing.

In previous studies (Spencer and Sanderson, 1994; Spencer, 1996) TL glow-curves from feldspar have been shown to be a composite of many thermodynamic components from continuously distributed trapping sites. The initial rise of the lowest glow-temperature peak following irradiation and thermal treatment can supply a quantitative indicator of thermal exposure, which relates to a combination of temperature and duration variables (Spencer and Sanderson, 1994; Spencer, 1996). Similarly for naturally accumulated signals where onset of a TL 'plateau' relates to onset of stability for charge retention over the accumulation period in question. Thus the lowest glow-temperature peak from archaeological TL responds to ambient thermal exposure (also combining duration and 
mean thermal history) of the environment in which the archaeological signal built up, whereas the lowest temperature peak from remnant 'geological' TL records thermal exposure due to the ceramic firing process. Both of these features are of archaeological and environmental interest. To analyse archaeological and remnant 'geological' peaks from natural TL glow-curves from all the Pool feldspars, we recorded glow-temperatures at the peak maximum $\left(T_{\max }\right)$ and at half the peak maximum on the initial rise $\left(T_{1 / 2}\right)$. These glowtemperature parameters are shown on Figure 2a for the first archaeological peak and for the first remnant 'geological' peak. The same glow-temperature parameters were also measured from the annealed peak of the laboratory TL curves (Fig. 2b). Although a detailed anomalous fading study was outside the scope of this work, this is not believed to have a significant influence on the preserved thermal history information in the glow curve shape. In the dating work described in Section 2 and studies elsewhere (e.g. Aitken, 1985; Sanderson, 1988a) fading tests do not show strong dependence on glow peak position, other than due to thermal fading losses, which are the dominant effect.

The presence of remnant 'geological' peaks were confirmed using a plateau plot in a similar manner to Figure $2 \mathrm{c}$. For a few samples the position of $\mathrm{T}_{\max }$ or $\mathrm{T}_{1 / 2}$ on the remnant 'geological' peak was obscured by other peaks in the continuum or was uncertain due to signal noise. Although the position of $\mathrm{T}_{1 / 2}$ is not a true mathematical inflection, if the HTTL data is differentiated sufficiently accurate $T_{1 / 2}$ and $T_{\max }$ data may be obtained from resultant maxima and minima, respectively (e.g. Fig. 2d). Alternatively, a stripping procedure was utilised; the laboratory TL was scaled and subtracted from natural TL and temperature parameters were determined on resultant stripped glow curve data. 
Table 2. Details of excavated sherds, TL dates and HTTL thermometric parameters

\begin{tabular}{|c|c|c|c|c|c|c|c|c|c|c|c|}
\hline \multirow{3}{*}{ Phase } & \multirow{3}{*}{ Context } & \multirow{3}{*}{$\begin{array}{l}\text { Finds } \\
\text { code }\end{array}$} & \multirow{3}{*}{ Fabric $^{2}$} & \multirow{3}{*}{$\begin{array}{c}\text { SUTL } \\
\text { no. }\end{array}$} & \multirow{3}{*}{$\begin{array}{l}\text { TL date } \\
\text { (yrs BC) }\end{array}$} & \multicolumn{6}{|c|}{ HTTL thermometric parameters $\left({ }^{\circ} \mathrm{C}\right)^{b}$} \\
\hline & & & & & & \multicolumn{2}{|c|}{ Archaeological } & \multicolumn{2}{|c|}{ Geological } & \multicolumn{2}{|c|}{ Laboratory } \\
\hline & & & & & & $T_{\max }$ & $\mathrm{T}_{1 / 2}$ & $T_{\max }$ & $T_{12}$ & $T_{\max }$ & $\mathrm{T}_{1 / 2}$ \\
\hline \multirow[t]{6}{*}{1.1} & 2776 & 6565 & Shell/Rock & $121 \mathrm{a}$ & $3660 \pm 750$ & 262 & 222 & $>700$ & $>650$ & 332 & 286 \\
\hline & 2886 & 6699 & No details & 122 & $4260 \pm 920$ & 264 & 227 & 534 & 481 & 340 & 283 \\
\hline & 2886 & 6700 & No details & 123 & $2930 \pm 580$ & 285 & 236 & $>700$ & $>650$ & 348 & 292 \\
\hline & 2886 & 6702 & No details & 125 & $3330 \pm 770$ & 299 & 237 & $>700$ & $>650$ & 345 & 287 \\
\hline & 2886 & 6704 & No details & 126 & $3840 \pm 860$ & 262 & 232 & $>700$ & $>650$ & 354 & 297 \\
\hline & 2776 & 6584 & Shell/Rock & 127 & $3960 \pm 1050$ & 297 & 237 & $>700$ & $>650$ & 362 & 293 \\
\hline \multirow[t]{5}{*}{2.1} & 1244 & 5189 & Un-tempered & $75 \mathrm{a}$ & $4020 \pm 830$ & 262 & 223 & 568 & 492 & 356 & 298 \\
\hline & 1244 & 5355 & Un-tempered & $78 \mathrm{a}$ & $3870 \pm 1180$ & 281 & 229 & 559 & $511^{5}$ & 349 & 298 \\
\hline & 1244 & 5360 & Shell & 79 & $4080 \pm 570$ & 263 & 225 & $584^{\mathrm{p}}$ & $544^{p}$ & 354 & 288 \\
\hline & 1330 & 5393 & Shell & 82 & $3370 \pm 650$ & 284 & 239 & 566 & $530^{d}$ & 339 & 282 \\
\hline & 1330 & 5394 & Shell & 83 & $4030 \pm 550$ & 277 & 229 & 659 & 616 & 353 & 285 \\
\hline \multirow[t]{7}{*}{2.2} & 1296 & 4972 & Shell & 26 & $3950 \pm 650$ & 282 & 230 & $567^{5}$ & $506^{5}$ & 304 & 266 \\
\hline & 1296 & 4929 & No details & 27 & $3500 \pm 500$ & 282 & 225 & 527 & $483^{x}$ & 324 & 279 \\
\hline & 1299 & 4935 & Un-tempered & 30 & $3920 \pm 650$ & 264 & 222 & 551 & 494 & 333 & 277 \\
\hline & 1302 & 5029 & Shell & 35 & $3310 \pm 510$ & 271 & 225 & 520 & 478 & 315 & 276 \\
\hline & 1299 & No record & No details & 32 & $1710 \pm 260$ & 285 & 232 & ? & ? & 359 & 283 \\
\hline & 1301 & 4973 & Shell & 33 & $1780 \pm 390$ & 273 & 240 & $571^{5}$ & $522^{5}$ & 324 & 279 \\
\hline & 1299 & 4933 & Shell & 29 & $2070 \pm 300$ & 282 & 232 & ? & ? & 340 & 275 \\
\hline \multirow[t]{7}{*}{$2.3 \mathrm{a}$} & 1289 & 4989 & Shell & 11 & $2320 \pm 370$ & 295 & 233 & ? & ? & 356 & 291 \\
\hline & 1289 & 4989 & Shell & 12 & $2300 \pm 340$ & 296 & 230 & 533 & 494 & 340 & 288 \\
\hline & 1289 & 4986 & Shell & 13 & $2260 \pm 400$ & 285 & 211 & 517 & 477 & 334 & 291 \\
\hline & 1289 & 4917 & Shell & 15 & $1840 \pm 290$ & 277 & 218 & 524 & 481 & 339 & 292 \\
\hline & 1289 & 4917 & Shell & 16 & $2070 \pm 350$ & 265 & 221 & 537 & 499 & 332 & 285 \\
\hline & 1294 & 4998 & Shell/Bone & 17 & $2370 \pm 380$ & 266 & 223 & 546 & 480 & 370 & 299 \\
\hline & $1294 / 1208$ & 5004 & Shell & 20 & $2190 \pm 370$ & 284 & 229 & 564 & 497 & 344 & 292 \\
\hline \multirow[t]{3}{*}{$2.3 \mathrm{~b}$} & 1228 & 4466 & Shell & 50 & $2110 \pm 280$ & 238 & 208 & 562 & 502 & 346 & 296 \\
\hline & 1236 & 4559 & Shell & 52 & $2060 \pm 300$ & 276 & 223 & ? & ? & 371 & 297 \\
\hline & $1236 / 1250$ & 4550 & Un-diagnostic & 54 & $2020 \pm 350$ & 265 & 229 & 571 & 541 & 355 & 285 \\
\hline \multirow[t]{2}{*}{3.1} & 0851 & 3402 & $70 \%$ Rock & 36 & $1870 \pm 360$ & 280 & 230 & 534 & 497 & 376 & 303 \\
\hline & 0851 & 3541 & $10 \%$ Rock & 38 & $2170 \pm 380$ & 281 & 239 & 560 & 520 & 325 & 276 \\
\hline
\end{tabular}

a Ceramic fabric analyses were carried out by MacSween (1990).

b Temperature parameters: ? = cannot determine although plateau indicates remnant geological TL present; $\mathrm{s}=$ determined by stripping methods; $\mathrm{p}=$ determined from normalisation plateau; $\mathrm{d}=$ determined by differentiation

\section{Results}

The $T_{\max }$ and $T_{1 / 2}$ data are summarised in Table 2 and Figure 3 . The data overall show very clear evidence that ceramics from the lowest phase have been consistently better fired than those tested from latter phases. Clearly there is a greater variation in temperature values from remnant 'geological' TL (Figs. 3c and 3d) compared to archaeological (Figs. 3a. and 3b) and laboratory (Figs. 3e and 3f) TL. For 5 of the 6 samples from Phase 1.1 (earliest Neolithic) evidence of natural HTTL peaks $>500^{\circ} \mathrm{C}$ is absent, whereas induced laboratory HTTL is observed up to $\sim 600-700^{\circ} \mathrm{C}$. This implies these samples have natural HTTL above detection limits (i.e. $\mathrm{T}_{\max }>700^{\circ} \mathrm{C}$ and $\mathrm{T}_{1 / 2}>\sim 650^{\circ} \mathrm{C}$; Figs. $3 \mathrm{c}$ and $3 \mathrm{~d}$; Table 2). The remaining samples have significantly lower values and, apart from sample SUTL82 from

Phase $2.1\left(\mathrm{~T}_{\max }=659^{\circ} \mathrm{C} ; \mathrm{T}_{1 / 2}=616^{\circ} \mathrm{C}\right)$, are clustered between $\mathrm{T}_{\max }$ of $517-584^{\circ} \mathrm{C}$ and $\mathrm{T}_{1 / 2}$ 
of $477-544^{\circ} \mathrm{C}$. Within these clusters, ceramics from Phase $2.3 \mathrm{a}$ have the lowest set of values. For 4 out of the 30 samples (SUTL11, 29, 32 and 52) temperature parameters could not be determined from remnant 'geological' peaks, although plateau plots confirmed presence of remnant 'geological' TL in these samples.
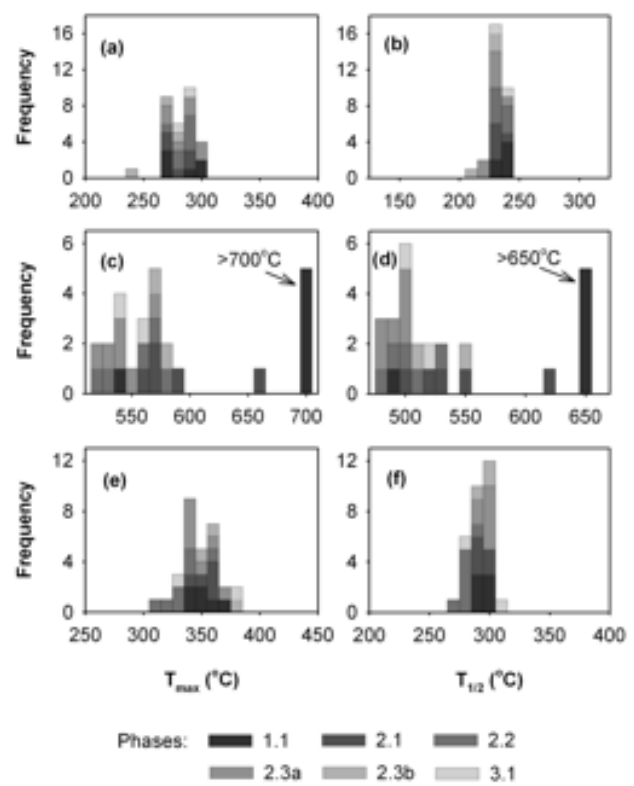

Figure 3. Histograms of $\mathrm{T}_{\max }$ and $\mathrm{T}_{1 / 2}$ parameters from each HTTL glow-curve measured (a) Archaeological $\mathrm{T}_{\max }$; (b) Archaeological $\mathrm{T}_{1 / 2}$; (c) Remnant 'geological' $\mathrm{T}_{\max }$; (d) Remnant 'geological' $\mathrm{T}_{1 / 2}$; (e) $\mathrm{T}_{\max }$ from annealed laboratory HTTL; (f) $\mathrm{T}_{1 / 2}$ from annealed laboratory HTTL. All histogram bins have $10^{\circ} \mathrm{C}$ intervals.

The tighter distribution in $\mathrm{T}_{1 / 2}$ compared with $\mathrm{T}_{\max }$ for both archaeological and laboratory TL data in Figure 3 clearly demonstrates that the $T_{1 / 2}$ parameter is a more precise measurement than $T_{\max }$, which is expected since the rate of change of the glow curve is highest at this part of the rising signal (e.g. Fig. 2d), whereas peak maxima can be rather broad and indistinct. The data shown in Figures $3 \mathrm{~b}$ and $3 \mathrm{f}$ is gratifying consistent, since although instrumental heating ramp reproducibility is very good $\left(\sim \pm 0.5^{\circ} \mathrm{C}\right.$ at $\left.700^{\circ} \mathrm{C}\right)$, the extent to which sample temperature follows the instrument depends on the consistency of 
thermal contact between sample, disc and heater, which is harder to assess. These observations confirm the validity of comparing temperature parameters.
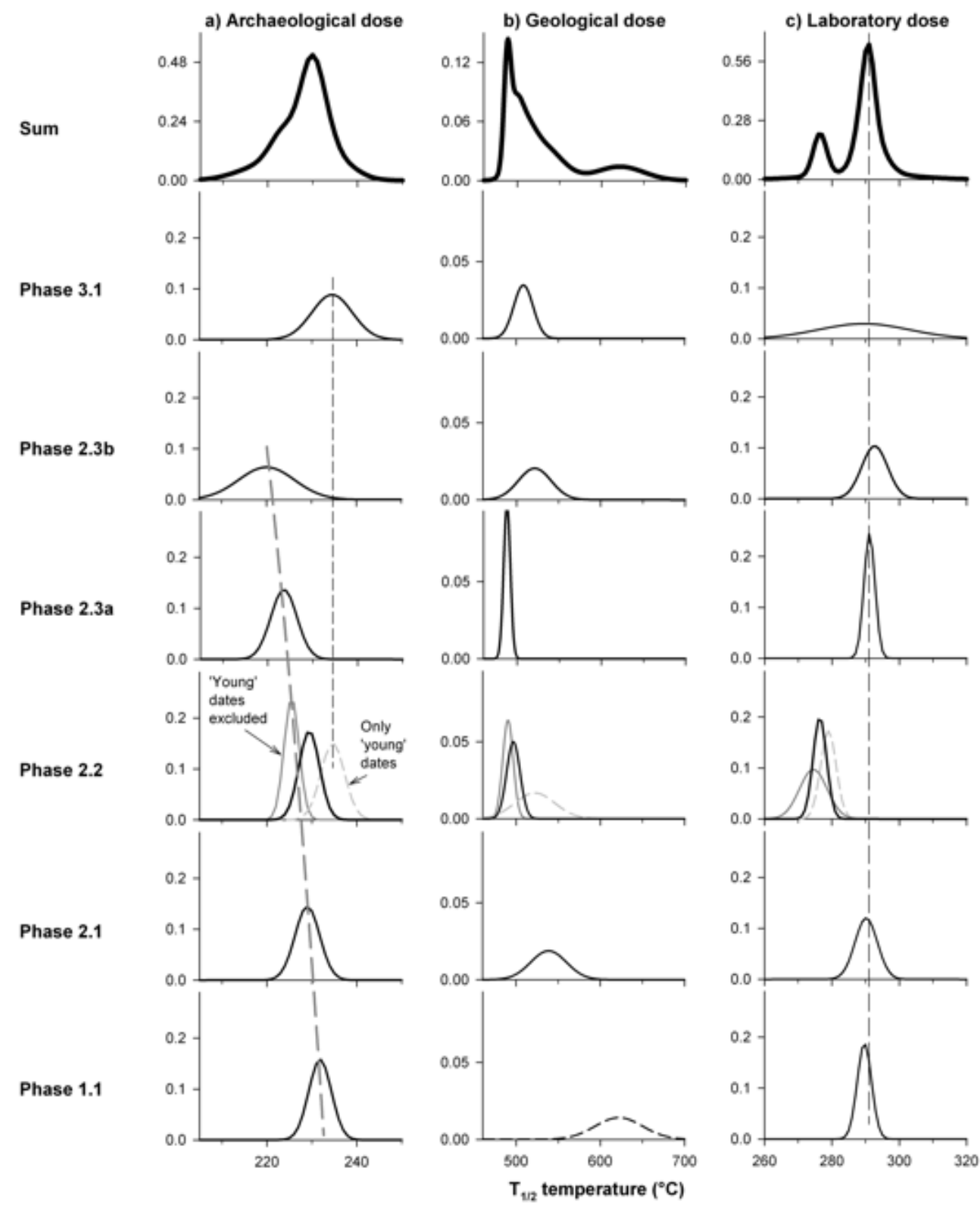

Figure 4. Graphical representation of mean $\mathrm{T}_{1 / 2}$ data using probability density function plots. (a) Archaeological; (b) Remnant 'geological'; (c) Laboratory. Uncertainties in mean are single standard errors $\left(\sigma_{\mathrm{n}-1} / \sqrt{ } \mathrm{n}\right)$.

Examining mean $\mathrm{T}_{1 / 2}$ data, the results for the remnant 'geological' TL (Fig. 4b) show a decreasing trend from Phase 1.1 to 2.3a, increasing again in Phase 2.3b and 3.1. Whereas 
remnant geological $\mathrm{T}_{1 / 2}$ is dependent on thermal exposure of ceramic firing, archaeological $\mathrm{T}_{1 / 2}$ is a function of temperature of burial environment and burial time or age (Section 6.2). The results for archaeological TL (Fig. 4a) show a subtle, but identifiable, decrease from Phase 1.1 to $2.3 \mathrm{~b}$, but rising again in Phase 3.1. Furthermore, if $\mathrm{T}_{1 / 2}$ values for the 3 samples with 'young' ages are removed from the Phase 2.2 mean $\mathrm{T}_{1 / 2}$ archaeological data, Phase 2.2 separates from 2.1 and the decreasing trend is maintained. The mean $T_{1 / 2}$ of the 3 samples with 'young' ages is coincident with Phase 3.1. For laboratory TL, the reason for departure from consistent mean $\mathrm{T}_{1 / 2}$ data in Phase 2.2 (Fig. 4c) is unclear. There is no discernible relationship between position of the discs on the copper plate and $\mathrm{T}_{1 / 2}$ values, which indicates the temperature across the plate was uniform during the heating cycle.

\section{Discussion}

\subsection{Remnant 'geological' $T_{1 / 2}$ : Decline in firing technology or poorer fuel resources?}

In the samples studied here it is not possible to say from style, fabric, decoration, dating evidence or glow-temperature parameters whether any of the ceramics from a particular phase were fired in the same simple bonfire or kiln. However, mean $\mathrm{T}_{1 / 2}$ results from remnant 'geological' HTTL (Fig. 4b) shows distinct variation between phases and low scatter within phases, and therefore indicate use of similar firing technologies and fuel management within phases, which differ from phase-to-phase. Furthermore, the distinct variation and low scatter in $\mathrm{T}_{1 / 2}$ indicate reasonably uniform thermal exposure over the ceramic during firing, rather than a variable thermal exposure across the ceramic surface. A 
Spencer and Sanderson: HTTL archaeothermometry of Neolithic ceramics from Pool

uniform thermal exposure implies that it is valid to compare $\mathrm{T}_{1 / 2}$ values from different phases in terms of a relative analysis.

The absence of remnant 'geological' HTTL for 5 out of 6 samples from Phase 1.1 (Fig. 3c and 3d) implies that ceramics from the earliest Neolithic were subjected to a far higher thermal exposure than ceramics from later phases. From Phase 1.1 there is an observable trend to lower thermal exposures until Phase $2.3 \mathrm{~b}$ and 3.1 (Fig. 4b). Here there is a rise in values once again, although sample size for $2.3 \mathrm{~b}$ and 3.1 is small and scatter relatively large. These results suggest that ceramic firing technology at Pool was more advanced for the earlier 'Unstan' tradition than the later 'Grooved Ware' tradition where we see a progressive decline, and there is possible indication of a variation in firing technology within the 'Grooved Ware' assemblages themselves. The possibility of the 'Grooved Ware' assemblages being brought to Pool from elsewhere (or vice versa for 'Unstan' material) may be dismissed because, although there is no physical evidence on site in terms of 'kilns' or wasters etc (Hunter, pers. comm.), MacSween identified that local clay sources were used throughout the Pool Neolithic (MacSween, 1990, 2007). Compared to the thermometry observations described here, there is no indication of a significant change in firing technology reflected in analyses of vessel form, decoration or temper (MacSween, 2007).

Decline in firing technology may accompany changes in society or cultural changes that develop in pace with adoption of a new ceramic tradition. At Pool the structural evidence indicates major changes taking place with Grooved Ware culture including buildings with 
specific work or craft functions (e.g. Structure 4, Phase 2), skillfully constructed architectural features such as 'casing' walls, and greater complexity in design, construction and function (e.g. Structure 8, Phase 3; Structure 14, Phase 3.2) (Hunter et al., 2007). These major structural changes were occurring in the context of a change to a widespread ceramic tradition with commonality of form and decoration of the broader later Neolithic community in Britain and within Ireland (Hunter et al., 2007). Similar contemporary structural evidence has been documented at Grooved Ware sites on the Orkney mainland e.g. at Skara Brae (Childe, 1931) and most recently at Barnhouse (Richards, 2005). At Barnhouse, changes in pottery decoration techniques, construction and use/disuse of monumental architecture, shifting consumption practices, and changes in house architecture and nature of settlement are all used to argue for a more inclusive form of social community by the later phases of the Later Neolithic (Jones 2002; Richards, 2005). The decline in firing technology at Pool may be a reflection of a change in emphasis from smaller and more basic social structures in the earlier Neolithic, utilising the finer craft of the individual potter, to a larger more inclusive settlement community in the later Neolithic at the expense of a poorer mass-produced ceramic product.

Alternatively, $\mathrm{T}_{1 / 2}$ results may be a reflection of available fuel resource from the Early to Late Neolithic at Pool. Similar firing methods may have been used, with a consistent duration of firing, but fuel resource may have changed or varied in abundance due to climatic factors, external aggression or a change of fuel due to exhaustion of nearby resources from over-foraging. Paleo-environmental evidence suggests colder temperatures by c. 3800 BC (Davidson and Jones, 1993), accompanied by a replacement of birch-hazel 
woodland, willow, ferns and tall herbs with more sparse open vegetation, higher wind speeds and wetter weather (Keatinge and Dickson, 1979). Aeolian sand layers covered the entire settlement at Pool on two separate occasions in the Neolithic (Hunter and MacSween, 1991; Hunter, 2000; Hunter et al., 2007). The lower of these, between Phases 2.1 and 2.2, is bracketed with TL dates to between $3889 \pm 303$ BC (Phase 2.1; weighted mean of SUTL samples 75a, 78a, 79, 82, 83) and 3606 $\pm 282 \mathrm{BC}$ (Phase 2.2; weighted mean of SUTL samples 26, 27, 30, 35), giving direct evidence of poorer weather conditions at Pool, which correlate with paleo-environmental evidence. Strong winds and salt spray inhibit tree growth, and evidence from Maes Howe and Stenness (Caseldine and Whittingdon, 1976) suggests a treeless landscape by $2600 \mathrm{BC}$. It seems feasible therefore, that $\mathrm{T}_{1 / 2}$ values reflect a decline in availability of higher temperature fuel derived from driftwood (Hunter et al., 2007), woodland or scrub after the earliest Neolithic, and more reliance on resources such as peaty turf, dung or 'loch peat' (Hunter et al., 2007) in the Mid-Late Neolithic due to climatic factors. Although evidence of seaweed as a fuel was not observed in the excavated material from Pool, this has also been shown to be a good fuel (e.g. Jones and Brown, 2000) and probable component of the 'cramp' samples analysed from Barnhouse (Stapleton and Bowman, 2005). A fuel resource interpretation is further supported by a stark stratigraphic contrast between black-to-red tipping deposits at Pool, believed to be due to a change in fuel source, which goes hand-in-hand with change from Unstan type to Grooved Ware pottery (Hunter et al., 2007).

The maximum TL age for the upper sand layer at Pool is $2162 \pm 133 \mathrm{BC}$ (Phase 2.3a; weighted mean of SUTL samples $11,12,13,15,16,17,20)$. This value is highly 
Spencer and Sanderson: HTTL archaeothermometry of Neolithic ceramics from Pool

concordant with an optically stimulated luminescence (OSL) date of $2210 \pm 135$ BC

(Sommerville et al., 2007) for a sand layer associated with the rich prehistoric landscape of Tofts Ness located on the northeast peninsula of Sanday (Fig. 1; Dockrill et al., 2007). The Tofts Ness sand blow event is potentially associated with site abandonment, and synchronous with Hekla 4 and with increased salinity records in Greenland ice cores (Sommerville et al., 2007). The presence of wind blown sands linked to climatic deterioration at Tofts Ness, and the relation of the two sites via sand markers and chronology, further supports a model of climatically driven fuel resource availability at Pool in the Mid-Late Neolithic.

The general expression relating $\mathrm{T}_{1 / 2}$ to isothermal annealing temperature $\left(\mathrm{T}_{\text {anneal }},{ }^{\circ} \mathrm{C}\right)$ and annealing time $\left(\mathrm{t}_{\text {anneal }}, \mathrm{s}\right)$ on a standard $\mathrm{K}$-feldspar is as follows: $\mathrm{T}_{1 / 2}=$ $23.9 \log _{10}\left(\mathrm{t}_{\text {anneal }}\right)+1.07\left(\mathrm{~T}_{\text {anneal }}\right)$; this relationship is derived from a constrained linear regression parallel line model analysis on data from a sequence of annealing experiments (Spencer and Sanderson, 1994; Spencer, 1996). For a $200^{\circ} \mathrm{C}$ anneal for $30 \mathrm{~min}(1800 \mathrm{~s})$ the expression gives a $\mathrm{T}_{1 / 2}$ value of $\sim 292^{\circ} \mathrm{C}$, which we see from Figures $3 \mathrm{f}$ and $4 \mathrm{c}$ is very close to measured $\mathrm{T}_{1 / 2}$ values from laboratory $\mathrm{TL}$. Uniform thermal exposure and, therefore, small thermal gradients are reasonable assumptions and we can therefore estimate firing temperatures. For example, assuming a firing duration of between $30 \mathrm{~min}$ and $6 \mathrm{~h}$, the Phase $1.1 \mathrm{~T}_{1 / 2}$ data $>650^{\circ} \mathrm{C}$ equates to firing temperatures between $>535^{\circ} \mathrm{C}(30 \mathrm{~min})$ and $>511^{\circ} \mathrm{C}(6 \mathrm{~h})$. Similarly, for Phase $2.3 \mathrm{a}\left(\right.$ mean $\left.\mathrm{T}_{1 / 2}=488^{\circ} \mathrm{C}\right)$ the expression derives firing temperatures between $383^{\circ} \mathrm{C}(30 \mathrm{~min})$ and $359^{\circ} \mathrm{C}(6 \mathrm{~h})$. These values suggest, particularly in the later Phases, that the firing temperatures involved were very low, which further 
Spencer and Sanderson: HTTL archaeothermometry of Neolithic ceramics from Pool

supports a theory of poorer fuels and fuel availability for production of later flat-based and 'Grooved Ware' ceramics at Pool.

\subsection{Archaeological $T_{1 / 2}$ : implications for luminescence dating}

The position of the first rise of the TL glow-curve is governed by a dynamic equilibrium between charge trapping in shallow traps and ambient temperature escape. Assuming a constant environmental dose-rate and burial temperature (or uniform burial temperature periodicity), the variable function is burial time or age (assuming time between firing and burial is negligible) and the longer the burial time (or older the sample) the higher the temperature of the first rise of the glow-curve. Analysis of archaeological $\mathrm{T}_{1 / 2}$ data phaseby-phase using the t-test, suggests mean data from Figure 4a are not significantly different. This outcome is not improved by normalising to artificial TL, which indicates samplespecific factors such as post-anneal glow-curve position, mineral purity, sample-disc geometry and mineral type, do not interplay.

Minerals tested from Phase 3.1 are out of sequence with an increasing $\mathrm{T}_{1 / 2}$ with age model. The reason for this is uncertain. The different fabric utilised in Phase 3 (Hunter et al. 2007; Table 2) may be a contributory factor or perhaps activities that led to midden burning or more recent burning of turf for soil improvement (Hunter et al., 2007) may have produced the small offset in glow curve data for Phase 3.1 material. 
Apart from Phase 3.1, mean $\mathrm{T}_{1 / 2}$ data do indicate a subtle decrease from the earliest to the latest phase and the general trend confirms both stratigraphic phasing and TL dating results.

Furthermore, removing $\mathrm{T}_{1 / 2}$ data for the 3 'young' dates from Phase 2.2 separates the mean $\mathrm{T}_{1 / 2}$ data for 2.2 from 2.1 and leaves them in the correct stratigraphic sequence. Although these observations are based on a small data set, and further detailed TL studies and assessment of additional factors such as variation of burial temperature with depth are required, this is a promising technique for adding additional support to, reassessing or dismissing, TL dates. Clearly, this technique has similar uses in OSL dating studies, since it only relies on ambient temperature modification.

\section{Conclusions}

Using an innovative high-temperature thermoluminescence approach we have objectively demonstrated that later Neolithic ceramics from Pool were very poorly fired. Furthermore the data overall show very clear evidence that pottery from the earliest Neolithic layers (possibly including examples of Unstan ware) has been consistently better fired compared to later layers (flat-based and grooved ware traditions). We suggest two interpretations of these data: either firing technology declined with changing social structures and/or adoption of a different ceramic tradition or that there was greater pressure on fuel resource and management in the later Neolithic. Paleoenvironmental and chronological evidence indicate climatic deterioration in the later Neolithic, which adds further support to an interpretation of a poorer fuel resource at that time. This latter interpretation implies that HTTL characteristics may be indirect monitors of changes in palaeoclimate. 
Analysis of the ambient temperature modification of the TL signal indicates a trend that confirms the stratigraphic phasing of the site and TL dating results, and is a useful technique for both TL and OSL dating which has potential to support or evaluate dating evidence.

This work adds to an increasing body of evidence of the existence of continuous trap distributions and deeper traps (above the typical $500^{\circ} \mathrm{C}$ TL range) in feldspars. These deeper traps may well have higher stability with luminescence signals less susceptible to anomalous fading. These are important observations at a time when the luminescence community is looking more and more at feldspar dating methods and ways to tackle signal instability.

Finally, the measurements described here are relatively straightforward to produce with reproducible high-temperature heating circuitry and suitable optical filters. The sample size required is not particularly large and there is no requirement for in-situ environmental dose reconstruction for TL thermometry - so museum collections potentially could be used.

\section{Acknowledgements}

John Hunter and Steve Dockrill are thanked for access to the Sanday archaeological sites, and access to the many ceramic, burned stone and aeolian sand samples of excavated 
material. Peter Clark and Andrew Dougans contributed significantly to the laboratory work associated with the TL age data reported here, which was part of a wider programme of support to Scottish Archaeology funded by Historic Scotland in the late 1980s. The HTTL and archaeothermometry work was supported by a quota studentship in Science Based Archaeology (to JQGS) from the Science and Engineering Research Council (SERC). 
Spencer and Sanderson: HTTL archaeothermometry of Neolithic ceramics from Pool

\section{Appendix A}

Table A.1. Details of excavated sherds and summary of TL dating results from separated alkali feldspars from the Pool Neolithic and Iron Age layers

\begin{tabular}{|c|c|c|c|c|c|c|c|c|c|c|c|c|c|c|c|c|}
\hline Phase & Context $^{2}$ & $\begin{array}{l}\text { Find } \\
\text { (PL\#\#) }\end{array}$ & Fabric $^{b}$ & Lab code & $\begin{array}{l}\text { Grain } \\
\text { Size } \\
(\mu \mathrm{m}) \\
\end{array}$ & $\begin{array}{c}\text { Density } \\
\text { Fraction } \\
\left(\mathrm{gcm}^{3}\right)\end{array}$ & $\begin{array}{c}\text { Plateau }^{\varepsilon} \\
\left({ }^{\circ} \mathrm{C}\right)\end{array}$ & $\begin{array}{l}\text { ED } \\
\text { (Gy) }\end{array}$ & I/ED & Fading & $\begin{array}{c}\mathrm{P} \\
\text { (Gy) }\end{array}$ & $\begin{array}{r}\mathrm{D}_{\text {itall }} \\
\text { (mGya }\end{array}$ & & $\begin{array}{l}\text { Age } \\
\text { (ka) }\end{array}$ & $\begin{array}{l}\text { Date } \\
\text { (yrs) }\end{array}$ & \\
\hline \multirow[t]{9}{*}{1.1} & 2776 & 6850 & No details & SUTL118 & $90-125$ & $2.58-2.62$ & $300-450$ & $17.41 \pm 1.30$ & $\cdot 0.04 \pm 0.09$ & $1.05 \pm 0.02$ & $17.02 \pm 1.37$ & $4.81 \pm 0$ & 0.68 & $3.54 \pm 0.58$ & $1550 \pm 580$ & $\mathrm{BC}$ \\
\hline & 2776 & 6584 & No details & SUTL119 & $90-125$ & $2.58-2.62$ & 360.470 & $15.78 \pm 0.57$ & $-0.05 \pm 0.08$ & $0.98 \pm 0.01$ & $16.31 \pm 0.64$ & $3.10 \pm 0$ & 0.37 & $5.25 \pm 0.67$ & $3260 \pm 670$ & $\mathrm{BC}$ \\
\hline & 2776 & 6565 & Shell/Rock & SUTL121a & $90-125$ & $2.58-2.62$ & $300 \cdot 400$ & $23.19 \pm 2.44$ & $0.02 \pm 0.01$ & $0.99 \pm 0.02$ & $23.92 \pm 2.56$ & $4.23 \pm 0$ & 0.33 & $5.65 \pm 0.75$ & $3660 \pm 750$ & $\mathrm{BC}$ \\
\hline & 2776 & 6585 & No details & SUTL121b & $90-125$ & $2.58-2.62$ & 300.400 & $23.19 \pm 2.44$ & $0.02 \pm 0.01$ & $0.93 \pm 0.01$ & $25.31 \pm 2.68$ & $4.29 \pm 0$ & 0.39 & $5.90 \pm 0.83$ & $3910 \pm 830$ & $\mathrm{BC}$ \\
\hline & 2886 & 6699 & No details & SUTL122 & $90-125$ & $2.51-2.58$ & 340.440 & $21.09=1.50$ & $0.00 \pm 0.02$ & $0.90 \pm 0.01$ & $22.28 \pm 1.64$ & $3.56 \pm 0$ & 0.45 & $6.25 \pm 0.92$ & $4260=920$ & $\mathrm{BC}$ \\
\hline & 2886 & 6701 & No details & SUTL124 & $90-125$ & $2.51-2.58$ & $350-450$ & $11.68 \pm 0.53$ & $-0.03 \pm 0.05$ & $0.96 \pm 0.01$ & $11.88 \pm 0.57$ & $3.20 \pm 0$ & 0.31 & $3.71 \pm 0.40$ & $1720 \pm 400$ & $\mathrm{BC}$ \\
\hline & 2886 & 6702 & No details & SUTL125 & $90-125$ & $2.51-2.58$ & $350-450$ & $19.97 \pm 0.80$ & $0.03 \pm 0.02$ & $0.89 \pm 0.07$ & $20.92 \pm 1.95$ & $3.93 \pm 0$ & 0.43 & $5.32 \pm 0.77$ & $3330 \pm 770$ & $\mathrm{BC}$ \\
\hline & 2886 & 6704 & No details & SUTL126 & $90-125$ & $2.58-2.62$ & $300-360$ & $16.06 \pm 0.56$ & $-0.04 \pm 0.08$ & $0.93 \pm 0.02$ & $17.02 \pm 0.72$ & $2.92 \pm 0$ & 0.41 & $5.83 \pm 0.86$ & $3840 \pm 860$ & $\mathrm{BC}$ \\
\hline & 2776 & 6584 & Shell/Rock & SUTL127 & $90-125$ & $2.62-2.74$ & 340.390 & $19.17 \pm 1.62$ & $-0.01 \pm 0.02$ & $1.03 \pm 0.01$ & $17.49 \pm 1.52$ & $2.94 \pm 0$ & 0.46 & $5.95 \pm 1.05$ & $3960 \pm 1050$ & $\mathrm{BC}$ \\
\hline \multirow[t]{10}{*}{2.1} & 1244 & 5189 & Untempered & SUTL75A & $90-125$ & $2.62-2.74$ & $320-370$ & $21.86 \pm 2.17$ & $0.04 \pm 0.01$ & $0.96 \pm 0.08$ & $22.74 \pm 2.91$ & $3.78 \pm 0$ & 0.20 & $6.01 \pm 0.83$ & $4020 \pm 830$ & $\mathrm{BC}$ \\
\hline & 1244 & 5340 & No details & SUTL 76A & $90-125$ & $2.62-2.74$ & 300.460 & $12.26 \pm 1.36$ & $-0.24 \pm 0.21$ & $1.03 \pm 0.02$ & $11.49 \pm 1.39$ & $3.52 \pm 0$ & 0.20 & $3.26 \pm 0.20$ & $1270 \pm 200$ & $\mathrm{BC}$ \\
\hline & 1244 & 5341 & No details & SUTL 77A & $90-125$ & $2.58-2.62$ & 300.450 & $12.22 \pm 0.90$ & $-0.16 \pm 0.09$ & $0.99 \pm 0.02$ & $12.17 \pm 0.94$ & $3.29 \pm 0$ & 0.23 & $3.70 \pm 0.38$ & $1710 \pm=380$ & $\mathrm{BC}$ \\
\hline & 1244 & 5355 & Untempered & SUTL78A & $90-125$ & $2.62-2.74$ & $310-340$ & $15.78 \pm 2.97$ & $-0.05 \pm 0.02$ & $0.90 \pm 0.02$ & $17.25 \pm 3.25$ & $2.94 \pm 0$ & 0.20 & $5.86 \pm 1.18$ & $3870 \pm 1180$ & $\mathrm{BC}$ \\
\hline & 1244 & 5360 & Shell & SUTL 79A & $90-125$ & $2.58-2.62$ & $340-400$ & $17.49 \pm 0.94$ & $0.06 \pm 0.10$ & $0.98 \pm 0.02$ & $17.59 \pm 1.04$ & $2.90 \pm 0$ & 0.21 & $6.07 \pm 0.57$ & $4080 \pm 570$ & $\mathrm{BC}$ \\
\hline & 1244 & 5391 & No details & SUTL80 & $90-125$ & $2.51 \cdot 2.58$ & $320 \cdot 380$ & $15.45 \pm 2.54$ & $\cdot 0.12 \pm 0.04$ & $1.08 \pm 0.05$ & $14.09 \pm 2.48$ & $2.89 \pm 0$ & 0.20 & $4.88 \pm 0.92$ & $2890 \pm 920$ & $\mathrm{BC}$ \\
\hline & 1330 & 5391 & No details & SUTL81 & $90-125$ & $2.58-2.62$ & $330-450$ & $14.11 \pm 0.84$ & $0.01 \pm 0.06$ & $0.93 \pm 0.02$ & $14.73 \pm 0.92$ & $3.41 \pm 0$ & 0.23 & $4.32 \pm 0.23$ & $2330 \pm 230$ & $\mathrm{BC}$ \\
\hline & 1330 & 5393 & Shell & SUTL\&2 & $90-125$ & $2.51-2.58$ & 370.400 & $15.61 \pm 1.67$ & $-0.14 \pm 0.11$ & $0.94 \pm 0.02$ & $17.09 \pm 1.80$ & $3.19 \pm 0$ & 0.19 & $5.36 \pm 0.65$ & $3370 \pm 650$ & $\mathrm{BC}$ \\
\hline & 1332 & 5394 & Shell & SUTL83 & $90-125$ & $2.58-2.62$ & 370.470 & $16.82 \pm 0.84$ & $-0.02 \pm 0.02$ & $1.00 \pm 0.01$ & $17.10 \pm 0.87$ & $2.84 \pm 0$ & 0.21 & $6.02 \pm 0.55$ & $4030 \pm 550$ & $\mathrm{BC}$ \\
\hline & 1244 & 5396 & No details & SUTL84 & $90-125$ & $2.58-2.62$ & $320-470$ & $7.92 \pm 0.67$ & $0.00 \pm 0.05$ & $0.94 \pm 0.01$ & $8.49 \pm 0.73$ & $3.56 \pm 0$ & 0.23 & $2.38 \pm 0.25$ & $390 \pm 250$ & $\mathrm{BC}$ \\
\hline \multirow[t]{10}{*}{2.2} & 1296 & 4972 & Shell & SUTL26 & $90-125$ & $2.58-2.62$ & $330-430$ & $17.55 \pm 1.09$ & $-0.01 \pm 0.06$ & $0.96 \pm 0.02$ & $18.11 \pm 1.42$ & $3.05 \pm 0$ & 0.24 & $5.94 \pm 0.65$ & $3950 \pm 650$ & $\mathrm{BC}$ \\
\hline & 1296 & 4929 & No details & SUTL27 & $90-125$ & $2.58-2.62$ & $330-450$ & $17.17 \pm 1.18$ & $0.03 \pm 0.02$ & $0.98 \pm 0.02$ & $18.32 \pm 1.30$ & $3.30 \pm 0$ & 0.24 & $5.55 \pm 0.56$ & $3560 \pm 560$ & $\mathrm{BC}$ \\
\hline & 1296 & 4931 & No details & SUTL28 & $90-125$ & $2.58-2.62$ & $330-430$ & $15,01 \pm 0.52$ & $-0.06 \pm 0.04$ & $0.97 \pm 0.01$ & $15.05 \pm 0.61$ & $3.33 \pm 0$ & 0.24 & $4.52 \pm 0.38$ & $2530 \pm 380$ & $\mathrm{BC}$ \\
\hline & 1299 & 4933 & Shell & SUTL29 & $90-125$ & $2.58-2.62$ & $300-430$ & $13.94 \pm 0.29$ & $0.03 \pm 0.02$ & $0.95 \pm 0.01$ & $14.65 \pm 0.33$ & $3.60 \pm 0$ & 0.25 & $4.06 \pm 0.30$ & $2070 \pm 300$ & $\mathrm{BC}$ \\
\hline & 1299 & 4935 & Untempered & SUTL30 & $90-125$ & $2.58-2.62$ & $330-430$ & $20.92 \pm 1.30$ & $0.01 \pm 0.01$ & $0.97 \pm 0.02$ & $21.15 \pm 1.37$ & $3.58 \pm 0$ & 0.21 & $5.91 \pm 0.52$ & $3920 \pm 520$ & $\mathrm{BC}$ \\
\hline & 1299 & 4936 & No details & SUTL31 & $90-125$ & $2.58-2.62$ & $300-430$ & $12.67 \pm 0.39$ & $0.79 \pm 3.64$ & $0.96 \pm 0.01$ & $13.10 \pm 0.45$ & $3.65 \pm 0$ & 0.20 & $3.59 \pm 0.23$ & $1600 \pm 230$ & $\mathrm{BC}$ \\
\hline & 1299 & & No details & SUTL32 & $90-125$ & $2.58-2.62$ & 350.430 & $13.30 \pm 0.35$ & $.0 .01 \pm 0.02$ & $0.96 \pm 0.01$ & $13.95 \pm 0.39$ & $3.78 \pm 0$ & 0.25 & $3.70 \pm 0.26$ & $1710 \pm 260$ & $\mathrm{BC}$ \\
\hline & 1301 & 4973 & Shell & SUTL33 & $90-125$ & $2.58-2.62$ & $320-410$ & $11.98 \pm 0.83$ & $0.04 \pm 0.04$ & $0.97 \pm 0.02$ & $12.33 \pm 0.89$ & $3.27 \pm 0$ & 0.24 & $3.77 \pm 0.39$ & $1780 \pm 390$ & $\mathrm{BC}$ \\
\hline & 1301 & 4987 & No details & SUTL34 & $90-125$ & $2.58-2.62$ & 340.420 & $16.30 \pm 0.71$ & $0.00 \pm 0.02$ & $0.96 \pm 0.02$ & $16.89 \pm 0.79$ & $3.36 \pm 0$ & 0.29 & $5.03 \pm 0.50$ & $3040 \pm 500$ & $\mathrm{BC}$ \\
\hline & 1302 & 5029 & Shell & SUTL35 & $90-125$ & $2.58-2.62$ & $330-430$ & $18.63 \pm 1.40$ & $0.00 \pm 0.00$ & $1.00 \pm 0.01$ & $18.63 \pm 1.40$ & $3.51 \pm 0$ & 0.21 & $5.30 \pm 0.51$ & $3310 \pm 510$ & $\mathrm{BC}$ \\
\hline \multirow[t]{10}{*}{$2.3 \mathrm{a}$} & 1289 & 4989 & Shell & SUTL11 & $90-125$ & $2.58-2.62$ & $340-430$ & $14.78 \pm 0.65$ & $-0.05 \pm 0.04$ & $1.01 \pm 0.01$ & $14.84 \pm 0.68$ & $3.44 \pm 0$ & 0.25 & $4.31 \pm 0.37$ & $2320 \pm 370$ & $\mathrm{BC}$ \\
\hline & 1289 & 4989 & Shell & SUTL12 & $90-125$ & $2.58-2.62$ & $280-380$ & $13.76 \pm 0.52$ & $0.01 \pm 0.05$ & $1.02 \pm 0.02$ & $13.83 \pm 0.58$ & $3.23 \pm 0$ & 0.22 & $4.29 \pm 0.34$ & $2300 \pm 340$ & $\mathrm{BC}$ \\
\hline & 1289 & 4986 & Shell & SUTL13A & 125.250 & $2.58-2.62$ & $300-400$ & $14.06 \pm 0.37$ & $0.09 \pm 0.01$ & $0.96 \pm 0.01$ & $14.05 \pm 0.43$ & $3.31 \pm 0$ & 0.29 & $4.25 \pm 0.40$ & $2260 \pm 400$ & $\mathrm{BC}$ \\
\hline & 1289 & 4986 & No details & SUTL14 & $90-125$ & $2.58-2.62$ & $310-420$ & $9.33 \pm 0.32$ & $0.04 \pm 0.03$ & $0.99 \pm 0.01$ & $9.42 \pm 0.33$ & $3.61 \pm 0$ & 0.35 & $2.61 \pm 0.27$ & $620 \pm 270$ & $\mathrm{BC}$ \\
\hline & 1289 & 4917 & Shell & SUTL15 & $90-125$ & $2.58-2.62$ & $300-420$ & $13.27 \pm 0.32$ & $0.04 \pm 0.02$ & $0.99 \pm 0.01$ & $13.31 \pm 0.36$ & $3.48 \pm 0$ & 0.25 & $3.83 \pm 0.29$ & $1840 \pm 290$ & $\mathrm{BC}$ \\
\hline & 1289 & 4917 & Shell & SUTL16 & $90-125$ & $2.51-2.58$ & $300-400$ & $14.11 \pm 0.42$ & $0.08 \pm 0.02$ & $1.04 \pm 0.02$ & $13.12 \pm 0.49$ & $3.23 \pm 0$ & 0.25 & $4.06 \pm 0.35$ & $2070 \pm 350$ & $\mathrm{BC}$ \\
\hline & 1294 & 4998 & Shell/Bone & SUTL17 & $90-125$ & $2.58-2.62$ & $280-340$ & $14.86 \pm 0.44$ & $0.04 \pm 0.02$ & $0.99 \pm 0.01$ & $14.89 \pm 0.48$ & $3.42 \pm 0$ & 0.28 & $4.36 \pm 0.38$ & $2370 \pm 380$ & $\mathrm{BC}$ \\
\hline & $1294 / 1208$ & 5004 & Shell & SUTL18 & $90-125$ & $2.58-2.62$ & $300-390$ & $8.50 \pm 0.52$ & $0.08 \pm 0.02$ & $0.84 \pm 0.01$ & $10.11 \pm 0.68$ & $3.01 \pm 0$ & 0.24 & $3.36 \pm 0.35$ & $1370 \pm 350$ & $\mathrm{BC}$ \\
\hline & $1294 / 1208$ & 5004 & Shell & SUTL19 & $90-125$ & $2.58-2.62$ & $350-430$ & $11.81 \pm 0.93$ & $0.06 \pm 0.03$ & $0.99 \pm 0.02$ & $11.70 \pm 0.95$ & $3.51 \pm 0$ & 0.24 & $3.33 \pm 0.36$ & $1340 \pm 360$ & $\mathrm{BC}$ \\
\hline & $1294 / 1209$ & 5004 & Shell & SUTL20 & $90-125$ & $2.58-2.62$ & 300.400 & $13.68 \pm 0.55$ & $0.03 \pm 0.03$ & $1.02 \pm 0.01$ & $13.56 \pm 0.59$ & $3.25 \pm 0$ & 0.25 & $4.18 \pm 0.37$ & $2190 \pm 370$ & $\mathrm{BC}$ \\
\hline
\end{tabular}

\begin{tabular}{|c|c|c|c|c|c|c|c|c|c|c|c|c|c|c|c|c|}
\hline Phase & Context ${ }^{2}$ & $\begin{array}{l}\text { Find } \\
\text { (PLif) }\end{array}$ & Fabric $^{b}$ & Lab code & $\begin{array}{l}\text { Grain } \\
\text { Size } \\
(\mu \mathrm{m})\end{array}$ & $\begin{array}{c}\text { Density } \\
\text { Fraction } \\
\left(\mathrm{gcm}^{-3}\right)\end{array}$ & $\begin{array}{c}\text { Plateaut }^{\epsilon} \\
\left({ }^{\circ} \mathrm{C}\right)\end{array}$ & $\begin{array}{l}\text { ED } \\
\text { (Gy) }\end{array}$ & 1/ED & Fading & $\begin{array}{c}\mathrm{P} \\
\text { (Gy) }\end{array}$ & 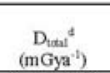 & $\begin{array}{l}\text { Age } \\
\text { (ka) }\end{array}$ & & $\begin{array}{l}\text { Date } \\
\text { (yrs) }\end{array}$ & \\
\hline \multirow[t]{10}{*}{$2.3 \mathrm{~b}$} & 1288 & 4466 & Shell & SUTL50 & $90-125$ & $2.58-2.62$ & $340-420$ & $14.02 \pm 0.46$ & $-0.12 \pm 0.22$ & $0.90 \pm 0.01$ & $15.32 \pm 0.51$ & $3.73 \pm 0.22$ & $4.10 \pm 0.28$ & $2110 \pm$ & 280 & $\mathrm{BC}$ \\
\hline & 1288 & 4466 & Shell & SUTLS0A & $90-125$ & $2.62-2.74$ & $330-430$ & $12.48 \pm 0.39$ & $.0 .06 \pm 0.05$ & $0.95 \pm 0.01$ & $13.30 \pm 0.44$ & $3.54 \pm 0.19$ & $3.76 \pm 0.23$ & $1770 \pm$ & 230 & $\mathrm{BC}$ \\
\hline & 1231 & 4468 & No details & SUTL51 & $90-125$ & $2.58-2.62$ & $300-430$ & $14.51 \pm 0.40$ & $0.02 \pm 0.01$ & $0.93 \pm 0.01$ & $15.97 \pm 0.45$ & $3.28 \pm 0.30$ & $4.88 \pm 0.47$ & $2890 \pm$ & 470 & $\mathrm{BC}$ \\
\hline & 1231 & 4468 & No details & SUTLS1A & $90-125$ & $2.51-2.58$ & $340-450$ & $14.58 \pm 0.55$ & $0.00 \pm 0.04$ & $0.98 \pm 0.01$ & $14.96 \pm 0.58$ & $3.03 \pm 0.21$ & $4.93 \pm 0.39$ & $2940 \pm$ & 390 & BC \\
\hline & 1236 & 4559 & Shell & SUTL52 & $90-125$ & $2.58-2.62$ & $330-430$ & $14.84 \pm 0.47$ & $0.04 \pm 0.02$ & $0.97 \pm 0.01$ & $15.22 \pm 0.50$ & $3.76 \pm 0.25$ & $4.05 \pm 0.30$ & $2060 \pm$ & 300 & $\mathrm{BC}$ \\
\hline & 1236 & 4559 & Shell & SUTL52A & $90-125$ & $2.51-2.58$ & $330-430$ & $13.79=0.26$ & $-0.01 \pm 0.01$ & $0.95 \pm 0.01$ & $14.41 \neq 0.28$ & $3.57 \pm 0.18$ & $4.04 \pm 0.21$ & $2050 \pm$ & 210 & $\mathrm{BC}$ \\
\hline & 1236 & 4559 & Shell & SUTL53 & $90-125$ & $2.58-2.62$ & $330-430$ & $14.25 \neq 0.74$ & $-0.03 \pm 0.03$ & $0.95 \pm 0.01$ & $15.07 \pm 0.80$ & $3.60 \pm 0.24$ & $4.19 \pm 0.36$ & $2200 \pm$ & 360 & $\mathrm{BC}$ \\
\hline & 1236 & 4559 & Shell & SUTL53A & $90-125$ & $2.51-2.58$ & 330.430 & $20.85 \pm 0.39$ & $0.03 \pm 0.02$ & $0.99 \pm 0.01$ & $21.51 \pm 0.48$ & $3.46 \pm 0.20$ & $6.21 \pm 0.39$ & $4220 \pm$ & 390 & $\mathrm{BC}$ \\
\hline & $1236 / 1250$ & 4550 & Undiagnostic & SUTL54 & $90-125$ & $2.58-2.62$ & $330-430$ & $12.20 \pm 0.48$ & $0.03 \pm 0.01$ & $0.98 \pm 0.01$ & $12.43 \pm 0.51$ & $3.10 \pm 0.24$ & $4.01 \pm 0.35$ & $2020 \pm$ & 350 & $\mathrm{BC}$ \\
\hline & $1236 / 1250$ & 4550 & Undiagnostic & SUTL54A & $90-125$ & $2.62-2.74$ & $320-440$ & $9.58 \pm 0.39$ & $0.02 \pm 0.05$ & $0.92 \pm 0.01$ & $9.84 \pm 0.42$ & $2.96 \pm 0.21$ & $3.32 \pm 0.28$ & $1330 \pm$ & 280 & $\mathrm{BC}$ \\
\hline \multirow[t]{10}{*}{3.1} & 0851 & 3402 & $70 \%$ Rock & SUTL36 & $90-125$ & $2.58-2.62$ & 370.450 & $15.70 \pm 0.90$ & $.0 .03 \pm 0.02$ & $0.97 \pm 0.01$ & $15.70 \pm 0.96$ & $4.06 \pm 0.28$ & $3.86 \pm 0.36$ & $1870 \pm$ & 360 & $\mathrm{BC}$ \\
\hline & 0851 & 3615 & $70 \%$ Rock & SUTL 36A & $90-125$ & $<2.51$ & $370-470$ & $14.34 \pm 0.46$ & $-0.01 \pm 0.02$ & $0.93 \pm 0.01$ & $15.31 \pm 0.51$ & $3.93 \pm 0.31$ & $3.90=0.33$ & $1910 \pm$ & 330 & $\mathrm{BC}$ \\
\hline & 0851 & 3456 & No details & SUTL37 & $90-125$ & $2.58-2.62$ & 380.450 & $11.05 \pm 0.32$ & $.0 .03 \pm 0.01$ & $0.89 \pm 0.01$ & $12.56 \pm 0.40$ & $2.36 \pm 0.21$ & $5.31 \pm 0.49$ & $3320 \pm$ & 490 & BC \\
\hline & 0851 & 3456 & No details & SUTL37A & $90-125$ & $2.51-2.58$ & $330-440$ & $22.50 \pm 1.01$ & $0.14 \pm 0.01$ & $0.96 \pm 0.01$ & $23.42 \pm 1.03$ & $2.60 \pm 0.19$ & $9.02 \pm 0.78$ & $7030 \pm$ & 780 & $\mathrm{BC}$ \\
\hline & 0851 & 3541 & $10 \%$ Rock & SUTL38 & $90-125$ & $2.58-2.62$ & $330-470$ & $11.27 \pm 0.63$ & $0.02 \pm 0.10$ & $0.93 \pm 0.01$ & $12.28 \pm 0.73$ & $2.95 \pm 0.21$ & $4.16 \pm 0.38$ & $2170 \pm$ & 380 & $\mathrm{BC}$ \\
\hline & 0851 & 3541 & $10 \%$ Rock & SUTL38A & $90-125$ & $2.51-2.58$ & $370-470$ & $16.33 \pm 0.38$ & $0.06 \pm 0.11$ & $1.03 \pm 0.01$ & $15.75 \pm 0.38$ & $2.91 \pm 0.33$ & $5.41 \pm 0.63$ & $3420 \pm$ & 630 & $\mathrm{BC}$ \\
\hline & 0851 & 3573 & No details & SUTL39 & $90-125$ & $2.58-2.62$ & 370.470 & $10.85 \pm 0.53$ & $-0.12 \pm 0.11$ & $0.94 \pm 0.02$ & $11.53 \pm 0.63$ & $3.72 \pm 0.25$ & $3.10 \pm 0.27$ & $1110 \pm$ & 270 & $\mathrm{BC}$ \\
\hline & 0851 & 3573 & No details & SUTL39A & $90-125$ & $2.51-2.58$ & $330-430$ & $18.28 \pm 0.45$ & $0.00 \pm 0.01$ & $0.94 \pm 0.01$ & $19.44 \pm 0.50$ & $3.87 \pm 0.33$ & $5.02 \pm 0.45$ & $3030 \pm$ & 450 & $\mathrm{BC}$ \\
\hline & 0851 & 3615 & No details & SUTL 40 & $90-125$ & $2.58-2.62$ & $320-420$ & $4.01 \pm 0.19$ & $-0.21 \pm 0.07$ & $1.01 \pm 0.01$ & $3.92 \pm 0.21$ & $3.38 \pm 0.23$ & $1.16 \pm 0.10$ & $830 \pm$ & 100 & $\mathrm{AD}$ \\
\hline & 0851 & 3615 & No details & SUTLA0A & $90-125$ & $2.51-2.58$ & $380-470$ & $3.80 \pm 0.22$ & $-0.15 \pm 0.06$ & $0.95 \pm 0.01$ & $4.05 \pm 0.23$ & $3.24 \pm 0.33$ & $1.25 \pm 0.15$ & $740 \pm$ & 150 & $\mathrm{AD}$ \\
\hline \multirow[t]{5}{*}{5.2} & 0759 & 3300 & Untempered & SUTL60 & $90-125$ & $2.58-2.62$ & $350-450$ & $4.41 \pm 0.23$ & $0.08 \pm 0.03$ & $0.88 \pm 0.01$ & $4.93 \pm 0.26$ & $2.89 \pm 0.26$ & $1.71 \pm 0.18$ & $280 \pm$ & 180 & $\mathrm{AD}$ \\
\hline & 0759 & 3300 & Untempered & SUTL61 & $90-125$ & $2.51-2.58$ & $330-450$ & $4.30 \pm 0.09$ & $.0 .03 \pm 0.03$ & $0.93 \pm 0.01$ & $4.61 \pm 0.10$ & $2.77 \pm 0.22$ & $1.67 \pm 0.13$ & $320 \pm$ & 130 & $\mathrm{AD}$ \\
\hline & 0759 & 3300 & Untempered & SUTL62 & $90-125$ & $2.51-2.58$ & $330-430$ & $5.25 \pm 0.10$ & $0.02 \pm 0.01$ & $0.94 \pm 0.01$ & $5.54 \pm 0.12$ & $2.68 \pm 0.22$ & $2.07 \pm 0.18$ & $80 \pm$ & 180 & $\mathrm{BC}$ \\
\hline & 0759 & 3300 & Untempered & SUTL63 & $90-125$ & $2.51-2.58$ & $330-430$ & $4.69 \pm 0.18$ & $0.01 \pm 0.01$ & $0.99 \pm 0.01$ & $4.71 \pm 0.18$ & $2.92 \pm 0.21$ & $1.61 \pm 0.13$ & $380 \pm$ & 130 & $\mathrm{AD}$ \\
\hline & 0759 & 3300 & Untempered & SUTL64 & $90-125$ & $2.51-2.58$ & $310-450$ & $4.92 \pm 0.09$ & $.0 .03 \pm 0.03$ & $0.96 \pm 0.01$ & $5.07 \pm 0.10$ & $2.80 \pm 0.21$ & $1.81 \pm 0.14$ & $180 \pm$ & 140 & $\mathrm{AD}$ \\
\hline \multirow[t]{10}{*}{6.1} & 0771 & 3292 & Untempered & SUTL55 & $90-125$ & $2.62 \cdot 2.74$ & $340-440$ & $5.24 \pm 0.17$ & $0.08 \pm 0.06$ & $0.98 \pm 0.01$ & $5.42 \pm 0.19$ & $3.79 \pm 0.22$ & $1.43 \pm 0.10$ & $560 \pm$ & 100 & $\mathrm{AD}$ \\
\hline & 0771 & 3311 & Untempered & SUTL56 & $90-125$ & $2.58-2.62$ & $330-440$ & $3.79 \pm 0.07$ & $.0 .05 \pm 0.06$ & $0.95 \pm 0.01$ & $3.98 \pm 0.08$ & $3.05 \pm 0.23$ & $1.30 \pm 0.10$ & $690 \pm$ & 100 & $\mathrm{AD}$ \\
\hline & 0771 & 3311 & Untempered & SUTL57 & $90-125$ & $2.51 \cdot 2.58$ & 360.460 & $3.62 \pm 0.20$ & $.0 .18 \pm 0.09$ & $0.96 \pm 0.01$ & $3.62 \pm 0.20$ & $3.35 \pm 0.21$ & $1.08 \pm 0.09$ & $910 \pm$ & 90 & $\mathrm{AD}$ \\
\hline & 0771 & 3325 & Untempered & SUTL58 & $90-125$ & $2.58-2.62$ & $330-430$ & $2.75 \pm 0.17$ & $-0.02 \pm 0.10$ & $0.88 \pm 0.01$ & $3.15 \pm 0.19$ & $3.13 \pm 0.24$ & $1.01 \pm 0.10$ & $980 \pm$ & 100 & $\mathrm{AD}$ \\
\hline & 0771 & 3325 & Untempered & SUTL59 & $90-125$ & $2.51-2.58$ & $330-440$ & $4.55 \pm 0.11$ & $0.02 \pm 0.03$ & $0.94 \pm 0.01$ & $4.78 \pm 0.12$ & $3.18 \pm 0.21$ & $1.50 \pm 0.11$ & $490 \pm$ & 110 & $\mathrm{AD}$ \\
\hline & 2591 & 2591 & $\mathrm{n} / \mathrm{a}$ (hearth) & SUTL128 & $90-125$ & $2.58-2.62$ & $350-450$ & $5.92 \pm 0.22$ & $-0.04 \pm 0.02$ & $0.83 \pm 0.02$ & $7.18 \pm 0.35$ & $4.47 \pm 0.35$ & $1.60 \pm 0.15$ & $390 \pm$ & 150 & $\mathrm{AD}$ \\
\hline & 2591 & 2591 & $\mathrm{n} / \mathrm{a}$ (hearth) & SUTL129 & $90-125$ & $2.62 \cdot 2.74$ & $320-360$ & $6.87 \pm 0.73$ & $.0 .04 \pm 0.02$ & $0.99 \pm 0.02$ & $7.14 \pm 0.77$ & $4.38 \pm 0.33$ & $1.63 \pm 0.22$ & $360 \pm$ & 220 & $\mathrm{AD}$ \\
\hline & 2591 & 2591 & n/a (hearth) & SUTL130 & $90-125$ & $2.58-2.62$ & $350-450$ & $5.80 \pm 0.19$ & $-0.11 \pm 0.10$ & $0.94 \pm 0.01$ & $6.18 \pm 0.21$ & $4.51 \pm 0.43$ & $1.37 \pm 0.14$ & $620 \pm$ & 140 & $\mathrm{AD}$ \\
\hline & 2591 & 2591 & n/a (hearth) & SUTL131 & $90-125$ & $2.58-2.62$ & $380-480$ & $8.08 \pm 0.76$ & $-0.12 \pm 0.09$ & $0.96 \pm 0.01$ & $8.52 \pm 0.80$ & $4.61 \pm 0.40$ & $1.85 \pm 0.24$ & $140 \pm$ & 240 & $\mathrm{AD}$ \\
\hline & 2591 & 2591 & n/a (hearth) & SUTL132 & $90-125$ & $2.62-2.74$ & 420.480 & $8.91 \pm 0.78$ & $-0.06 \pm 0.02$ & $1.13 \pm 0.02$ & $795 \pm 0.72$ & $4.59 \pm 0.48$ & $1.73 \pm 0.24$ & $260 \pm$ & 240 & $\mathrm{AD}$ \\
\hline
\end{tabular}

A slash ( 7 ) indicates interface between contexts

(1990).

c TL temperature plateau over which equivalent dose (ED), second-glow intercept correction (1) and fading result are calculated. Palaeodose (P) is ED+I adjusted for fading estimate.

d Combined result of dose-rates due to effective beta, in-situ gamma, cosmic and internal dose estimates. See Section 2 for further details. 
Spencer and Sanderson: HTTL archaeothermometry of Neolithic ceramics from Pool

\section{Appendix B. Supplementary material}

Supplementary material associated with this article is a geospatial data file (mmc1.kmz) of the study area. This file can be opened using Google Earth.

\section{References}

Aitken, M.J., 1985. Thermoluminescence dating. Academic Press, London.

Alexander, S.A., 2007. The stability of the remnant luminescence emissions of alkali feldspar. Unpubl. Ph.D thesis, Univ. Glasg.

Bailiff, I.K., 1976. Use of phototransfer for the anomalous fading of thermoluminescence. Nature 264, 531-533.

Bowman, S.G.E., 1979. Phototransferred thermoluminescence in quartz and its potential use in dating. PACT 3, 381-400.

Brou, R., Valladas, G., 1975. Appareil pour la mesure de la thermoluminescence de petits échantillons. Nucl. Instrum. Methods 127, 109-113. 
Spencer and Sanderson: HTTL archaeothermometry of Neolithic ceramics from Pool

Caseldine, C.J., Whittingdon, G., 1976. Pollen analysis of material from the Stones of Stenness, Orkney. In: The Stones of Stenness, Orkney (J.N.G. Ritchie) Proceedings of the Society of Antiquarians of Scotland 107, 37-40.

Childe, V.G., 1931. Skara Brae, a Pictish village in Orkney. Kegan Paul, London.

Davidson, D.A., Jones, R.L., 1993. The Environment of Orkney. In: The Prehistory of Orkney (ed. A.C. Renfrew), 3rd Edition, Edinb. Univ. Press, 10-35.

Dockrill, S.J., Bond, J.M., Smith, A.N., Nicholson, R.A., 2007. Investigations in Sanday Orkney Volume 2: Tofts Ness Sanday, An Island Landscape Through 3000 Years of Prehistory. The Orcadian Ltd in association with Historic Scotland, Kirkwall, Orkney.

El-Kolaly, M.A., Rao, S.M.D., Nambi, K.S.V., Ganguly, A.K., 1980. Observations on a high temperature peak in the thermoluminescence of fluorites. Pramana 14, 165-173.

Ganguly, S., Kaul, I.K., 1984. Analysis of thermoluminescence glow peaks from natural calcium fluoride. Modern Geology 8, 155-161.

Guérin, G., Valladas, G., 1980. Thermoluminescence dating of volcanic plagioclases. Nature 286, 697-699. 
Spencer and Sanderson: HTTL archaeothermometry of Neolithic ceramics from Pool

Hunter, J.R., 2000. Pool, Sanday and a sequence for the Orcadian Neolithic. In: Neolithic Orkney in its European Context (ed. A. Ritchie), McDonald Institute for Archaeological Research, 117-125.

Hunter, J.R., Bond, J.M., Smith, A.N., 2007. Investigations in Sanday, Orkney Volume 1: Excavations at Pool Sanday. A multi-period settlement from Neolithic to Late Norse times. The Orcadian Ltd in association with Historic Scotland, Kirkwall, Orkney.

Hunter, J.R., MacSween, A., 1991. A sequence for the Orcadian Neolithic? Antiquity 65, 911-914.

Jones, A., 2002. Archaeological theory and scientific practice. Cambridge University Press.

Jones, R.E., Brown, B., 2000. Neolithic pottery-making in Orkney: a new look. In: Neolithic Orkney in its European Context (ed. A. Ritchie), McDonald Institute for Archaeological Research, 169-184.

Keatinge, T.H., Dickson, J.H., 1979. Mid-Flandrian changes in vegetation on Mainland Orkney. New Phytol. 82, 585-612.

MacSween, A., 1990. The Neolithic and Late Iron Age pottery from Pool, Sanday, Orkney. Unpubl. Ph.D thesis, Univ. Bradf. 
Spencer and Sanderson: HTTL archaeothermometry of Neolithic ceramics from Pool

MacSween, A., 2007. The artefactual evidence: the pottery. In: Investigations in Sanday, Orkney Volume 1: Excavations at Pool Sanday. A multi-period settlement from Neolithic to Late Norse times (eds. A.N. Smith, J.R. Hunter), The Orcadian Ltd in association with Historic Scotland, Kirkwall, Orkney, 287-353.

Mejdahl, V., 1979. Thermoluminescence dating: beta dose attenuation in quartz grains. Archaeometry 21, 61-73.

Mejdahl, V., 1983. Feldspar inclusion dating of ceramics and burnt stones. PACT 9, 351364.

Mejdahl, V., 1985. Thermoluminescence dating based on feldspars. Nucl. Tracks Radiat. Meas. 10, 133-136.

Mejdahl, V., Winther-Nielsen, M., 1982. TL dating based on feldspar inclusions. PACT 6, 426-437.

Richards, C., 2005. Dwelling among the monuments: the Neolithic village of Barnhouse, Maeshowe passage grave and surrounding monuments at Stenness, Orkney. Cambridge University Press.

Sanderson, D.C.W., 1988a. Fading of thermoluminescence in feldspars: Characteristics and corrections. Nucl. Tracks Radiat. Meas. 14, 155-161. 
Spencer and Sanderson: HTTL archaeothermometry of Neolithic ceramics from Pool

Sanderson, D.C.W., 1988b. Thick source beta counting (TSBC): A rapid method for measuring beta dose-rates. Nucl. Tracks Radiat. Meas. 14, 203-207.

Sanderson, D.C.W., Chambers, D.A., 1985. An automatic 90-Sr irradiator for TL dating. Ancient TL 3, 26-29.

Sanderson, D.C.W., Placido, F., Tate, J.O., 1985. Scottish vitrified forts: background and potential for TL dating. Nucl. Tracks Radiat. Meas. 10, 799-809.

Sanderson, D.C.W., Placido, F., Tate, J.O., 1988. Scottish vitrified forts: TL results from six study sites. Nucl. Tracks Radiat. Meas. 14, 307-316.

Sommerville, A.A., Hansom, J.D., Housley, R.A., Sanderson, D.C.W., 2007. Optically stimulated luminescence (OSL) dating of coastal aeolian sand accumulation in Sanday, Orkney Islands, Scotland. Holocene 17, 627-637.

Spencer, J.Q., Sanderson, D.C.W., 1994. Mapping thermal exposure by luminescence thermometry. Radiat. Meas. 23, 465-468.

Spencer, J.Q., 1996. The development of luminescence methods to measure thermal exposure in lithic and ceramic materials. Unpubl. Ph.D thesis, Univ. Glasg. 
Spencer and Sanderson: HTTL archaeothermometry of Neolithic ceramics from Pool

Stapleton, C.P., Bowman, S.G.E., 2005. An examination of the cramp from Barnhouse and Mouseland, Mainland, Orkney. In: Dwelling among the monuments (ed. C. Richards), McDonald Institute for Archaeological Research, 381-384.

Sunta, C.M., 1979. Mechanism of phototransfer of thermoluminescence peaks in natural $\mathrm{CaF}_{2}$. Phys. Stat. Sol. (a)53, 127-135.

Valladas, G., Gillot, P.Y., Guérin, G., 1979. Dating plagioclase? PACT 3, 251-257.

Wintle, A.G., 1973. Anomalous fading of thermoluminescence in mineral samples. Nature $245,143-144$.

Wintle, A.G., 1977. Detailed study of a thermoluminescent mineral exhibiting anomalous fading. J. Lumin. 15, 385-393. 